Copyright (C) 2016 by Academic Publishing House Researcher

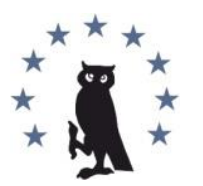

Published in the Russian Federation

European Researcher

Has been issued since 2010.

ISSN 2219-8229

E-ISSN 2224-0136

Vol. 110, Is. 9, pp. 481-484, 2016

DOI: $10.13187 /$ er.2016.110.481

www.erjournal.ru

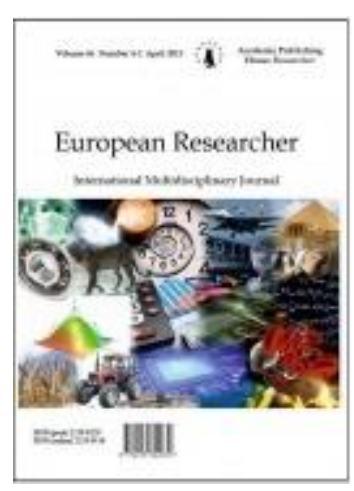

\title{
Relevant Topic
}

\section{UDC 002}

\section{For the Anniversary Edition of the Scientific Journal European Researcher. Series A - 110 issue}

\author{
${ }^{1}$ Goran Rajović \\ ${ }^{2}$ Jelisavka Bulatović
}

\author{
${ }^{1}$ International Network Center for Fundamental and Applied Research, Russian Federation \\ E-mail: dkgoran.rajovic@gmail.com. \\ ${ }^{2}$ College of Textile Design, Technology and Management, Belgrade, Serbia \\ E-mail address: jelisavka.bulatovic@gmail.com
}

\begin{abstract}
This article is a review of the jubilee scientific journal "European Researcher. Series A ", marked at all in 2016 - the sixth anniversary, of regular and of continuous publication. In addition to the history of the newspaper are exposed to the development phase of its program concept. The journal is the period 2010 - 2016 year, profiled in an important factor of development and the formation of professional and scientific thought. Journal "European Research. Series A" is now open forum for publicizing and stimulating innovative thinking on all aspects of the social sciences, the entire international academic community. In all this we emphasize the infinite persistence, creative energy but also authoring and management merits chief editor and founder of the Journal, Dr Aleksandr Cherkasov for survival and development for this great publishing project.

Keywords: European Researcher. Series A, jubilee, editorial concept, Aleksandr Cherkasov.

Jubilees are generally the important thing in the life of people and institutions. It is customary to jubilees marked at intervals of $100,75,50,25$ or 10 years, but we believe that the figure is 6 years old, important and worthy of respect. Specifically, in this, the year 2016, and published the journal volume 110 of the "European Researcher. Series A"(in encounter jubilee 01. November). All of these volumes of journals have "brought forth" and "live" with a sincere commitment to science and profession. The upcoming anniversary is a great opportunity to European Researcher. Series A, on the best way affirms the achieved results and establish the direction for further development and promotion of research.

Journal "European Researcher. Series A", is scientific journal Academic Publishing House Researcher, Russian Federation and it's the mission is the publication of high quality research results made in the field of social sciences. Such areas as history, psychology, economics, philosophy, cultural studies, political science and law are the top priorities of the Editorial Board of journal. The goal of are journal "European Researcher. Series A" is to familiarize the scientific public with the research results and their interpretation which are relevant to current social issues.
\end{abstract}


An unusual combination of practical and theoretical data, the inherent attention to many issues of social disciplinary in a significant part of the publications are distinguishing features of journal. The journal publishes conference proceedings, articles and short reports, concerning the results of social research in the Russian and English languages (Academic Publishing House Researcher, 2016).

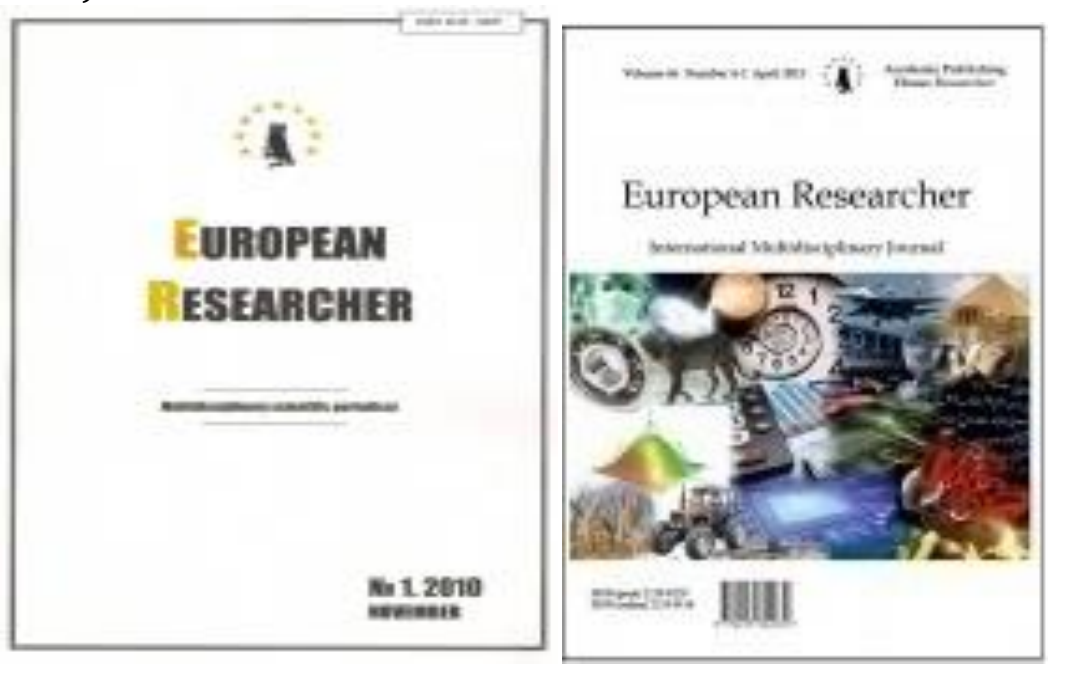

Fig. 1. Appearance of the journal "European Researcher. Series A" - 2010 and 2016.godine (Academic Publishing House Researcher, 2016).

Conceptually, the journal contains a well-designed range of different sections - from scientific research to current scientific information, dealing with important scientific topics and their orientation towards social - economic practices and making responses the current socio - economic issues, which is why the "European Researcher. Series A", useful and researchers to practitioners, are especially those who choose to use the experience of others in your own work.

Content-wise, it seems reasonable that and in this journal has the highest contributions in the field of economic sciences (360), i.e., the works of pedagogical sciences (200), although not far behind, either in quality or in numbers, works in the field of philological sciences (159) historical sciences and archeology (131)... In this respect, it is understandable and bridge that this influential journal generated between different countries, especially in the field of social research.

Technically, there are notable differences in the format of the journal and the tidiness articles in relation on most other of the journal (Vukadinović, 2016). Bearing in mind the bigger picture, the creation and support of issues of the journal, it seems that they are primarily a result of seeking inspiration in Russian journals. The journal is slightly larger format, and articles begin abstracts and keywords, or introduction, materials and methods, discussion and references, as is the custom settled practice of issuing this type of serial publications. All supplements generally contain a summary translation in two languages - Russian and English, and have access to a summary of the requirements not only satisfied but, bearing in mind the usual standards, and exceeded, because this Journal has enabled bilingualism availability of basic ideas and attitudes of each author significantly wider circle readers. As typical of scientific journal "European Researcher Series A" is contains detailed instructions for authors of the call for submission of papers.

For a short period 2010 - 2016 in the scientific community Journal is revealed as a witness, but also protagonist, the development of scientific thought and the profession and becomes recognizable and deservedly distinguished by the quality of published scientific, professional and review articles, equipment exemplary contributions and technical arrangement of each number. In previous numbers (from 01 November, 2010 to 31 August, 2016) journal "European Researcher Series A"is represented total of 1.681 articles. These articles proposed by the 3.215 authors from 55 countries, with five continents: Europe, Africa, Asia, North America, South America and Australia. Besides researchers from the Russian Federation and the former space Soviet Union for European Researcher. Series A, for six years have published articles and colleagues from Italy, Greece, Germany, Egypt, Israel, Iran, India, Pakistan, Malaysia, China ... fact is worthy of respect. 
The quality of authors' contributions blackmailed by renowned reviewers of Russian Federation and from abroad.

The journal is subjected to constant evaluation (monitoring) depending of influence (the impact of) at the base Russian Science Citation Index and, complementary, in international citation indexes (Rajović and Bulatović,2016). In the context of Russian Science Citation Index, Impact factor in 2014 je 0.415 and Information Matrix for the Analysis of Journals ICDS in 2016 - 5.800. Impact factor of MIAR journal "European Researcher Series A“is in 2012 - 3.301, 2013 - 3.477, 2014 - 5.602 and 2015 - 5.699 (Academic Publishing House Researcher, 2016),

A large contribution for this rise of the journal definitely belong to the editor chief $\mathrm{Dr}$ Aleksandr Cherkasov with International Network Center for Fundamental and Applied Research from Russian Federation, including of course the editorial board, consisting of: Bazhanov Evgeny with Diplomatic Academy Ministry of Foreign Affairs from Russian Federation; Beckman Johan with University of Helsinki from Finland; Biryukov Pavel with Voronezh State University from Russian Federation; Goswami Sribas with Serampore College from India; Dogonadze Shota with Georgian Technical University from Georgia; Krinko Evgeny with Southern Scientific Centre of RAS from Russian Federation; Malinauskas Romualdas with Lithuanian Academy of Physical Education from Lithuanian; Markwick Roger with University of Newcastle from Australia, Md Azree Othuman Mydin with Universiti Sains Malaysia from Malaysia; Menjkovsky Vaycheslav with University of Belarusian State from Belarus; Müller Martin with University St. Gallen, St. Gallen from Switzerland; Ojovan Michael with Imperial College London from UK; Ransberger Maria with University of Bayreuth from Germany and Šmigel' Michal with Matej Bel University from Slovakia (Academic Publishing House Researcher, 2016). Of course, great merits the given by the executive editors Violetta Molchanova and Sergey N. Nikitin.

In the coming period priorities of the editorial board will be just continue to strengthen the reputation of the newspaper, as well as work on its visibility and distinctiveness. For are these reasons, and in order to further improve the quality of the journal of the European Researcher. Series A, the editorial team will be widened, and to colleagues who, collaborators, and over the past six years has significantly contributed to the development of the journal.

We hope that and this 110 number of the journal "European Researcher. Series A", be received just as well as the previous one and will attract the attention of many colleagues and all readers who follow the issues in the field history, psychology, economics, philosophy, cultural studies, political science, law... On behalf of the editorial board of the journal would like to thank all who have contributed and in many other ways contributed to the preparation of 110 regular issue of the journal "European Researcher. Series A", or the previous numbers. Special thanks, as ever, we owe reviewers, who have significantly contributed to the quality of published papers, and journal in general.

In the belief that there is still many interesting regular numbers (Electronic Journal for "Communication and Culture Online", 2014), we leave 110 of the journal "European Researcher. Series A", Court of scientific and professional community and we invite all interested colleagues with the permission of the editor in chief Dr Aleksandr Cherkasov and Editorial Board journal „European Researcher. Series A“, yes enrich forward mentioned journal with their scientific articles, criticism, polemics, but also our Academic Publishing House Researcher their monographs, textbooks, manuals ... We look forward to continuing already started, and the establishment of new cooperation, and with thanksgiving we expect your suggestions, ideas and comments.

In the end, it is not easy to judge one time section large and significant of the whole (Gaceša and Jovanović, 2012). Consider, even the 110 anniversary issue of the "European Research. Series A", is impossible without thinking about what the magazine already is or what it could be. However, it seems to us yes journal „European Researcher. Series A“, within its wide content located room for advances, especially in the interdisciplinary research approach. In the assessment of individual scientific contributions in this edition of 110 , as well as any future issue, it would be important to keep the thought how the is journal "European Researcher. Series A", had and has the potential (more precisely, during the publishing its quality was gained) to continue to be a significant support to researchers as a source of new knowledge, but also as a place where they can publish their research results. 
In all this we emphasize the infinite persistence, creative energy but also authoring and management merits chief editor, founder of the Journal and director Academic Publishing House Researcher Dr Aleksandr Cherkasov for survival and development for this great publishing project. Unselfish support in the work of Dr Aleksandr Cherkasov given are and members team Academic Publishing House Researcher in composition: Violetta Molchanova - Russian Federation, Anvar Mamadaliev - Russian Federation, Natalya Shevchenko - Russian Federation, Alisa Konovalova Russian Federation, Tim Kazbeckoff - Russian Federation (staff), Sribas Goswami - India, Sergei Degtyarev - Ukraine, Diana Ismailova - Kazakhstan, Jacob Sarfo - Ghana, Ia Shiukashvili - Georgia ,Timur Magsumov - Russian Federation (official regional representatives) and Michal Šmigel' Slovakia, Pavol Bartik - Slovakia, Md Azree Othuman Mydin - Malaysia, Stefan Aufenanger Lithuania,Romualdas Malinauskas - Lithuania, Martin Müller - Germany, Zekeriya Karadag Turkey, Rushan Ziatdinov - South Korea, Evgeniya Vidishcheva - Russian Federation, Yury Tyunnikov - Russian Federation (staff editorial boards).

\title{
References
}

1. Academic Publishing House Researcher (2016), European Researcher. Series A (Social sciences), Available from: http://www.aphr.ru (24.07 2016).

2. Vukadinović, S.,(2016), New Law Review - anniversary edition of the journal that connects, Pravni zapisi, VII(1), 162 - 167.

3. Rajović, G., Bulatović, J., (2016), The Russian Historical Journal "Bylye Gody" (20062016 years): the Results of the First Decade, Bylye Gody, 41(3), 550-554.

4. Electronic Journal for language, communication, culture and society "Communication and Culture Online" (2014), Introductory word, Available from: http://www.komunikacijaikultura.org (25.07 2016).

5. Gaćeša, N. N., Jovanović, Z. D., (2012), Sixty years of the Military Technical Courier: All our jubilees, Vojnotehnički glasnik, 6o(3), 7-41.

\section{УДК 002}

\section{К юбилею издания научного журнала European Researcher. Series A - 110 выпуск}

\author{
${ }^{1}$ Горан Райович \\ 2 Джелисавка Булатович
}

\begin{abstract}
${ }^{1}$ Международный сетевой центр фундаментальных и прикладных исследований, Российская Федерация

E-mail address: dkgoran.rajovic@gmail.com

2 Колледж текстильного дизайна, технологии и управления, Белград, Сербия

E-mail address: jelisavka.bulatovic@gmail.com
\end{abstract}

Аннотация. Данная статья представляет собой обзор - 2016 к юбилею научного журнала «European Researcher. Series A»- его шестой годовщине со дня регулярного и непрерывного издания. В дополнение к истории журнала в обзоре даны концепции развития. Журнал зарекомендовал себя как издание, публикующее материалы по развитию и формированию профессиональной и научной мысли. Журнал «European Researcher. Series A» специализируется на популяризации и стимулировании инновационного мышления во всех аспектах социальных наук среди всего международного научного сообщества. В этом процессе мы подчеркиваем бесконечную настойчивость, творческую энергию по созданию и ведению издания - главного редактора и основателя журнала, д-р Александра Черкасова, его усилия, направленные на поддержку этого интересного издательского проекта.

Ключевые слова: European Researcher. Series A, юбилейный, редакционная концепция, Александр Черкасов. 